Brit. J. industr. Med., 1958, 15, 8.

\title{
IMMUNOLOGICAL FACTORS IN THE PATHOGENESIS OF THE HYALINE TISSUE OF SILICOSIS
}

\author{
BY \\ E. C. VIGLIANI and B. PERNIS \\ From the Institute of Industrial Medicine, University of Milan \\ (RECEIVED FOR PUBLICATION MAY 15, 1957)
}

Several hypotheses have been suggested in explanation of the pathogenesis of silicosis. The earliest was the mechanical hypothesis, according to which, quartz particles, being pointed and sharp, would irritate the cells, stimulating their proliferation. This hypothesis was discarded when it was seen that other minerals, with edges even harder and sharper than quartz, such as carborundum and diamond, did not produce fibrosis. In 1922 Gye and Purdy put forward the chemical theory. They suggested that silicic acid, on being slowly released by crystalline silica, would react as a toxic substance capable of inducing fibrosis. This hypothesis was long held, and until a short time ago it was supported and expanded by King (1947) and his colleagues. It was never clearly established how the dissolved silicic acid actually produced fibrosis. It was believed by some that monosilicic acid was the fibrogenic agent, and by others that it was polymerized silicic acid. However, no conclusive evidence has been produced to show that the dissolved silica induces fibrosis and by what means, and this is true also for the interesting hypothesis, recently put forward by Kikuth (1956), which focuses attention on the damage which monomeric silicic acid may exert on some cellular structures (mitochondria).

In the last 10 years several physical hypotheses have been proposed: the piezoelectric (Velicogna, 1946; Evans, 1948) and radioactivity of quartz theories (Dantin-Gallego, 1948), both found unacceptable by Parmeggiani (1950), and also the most interesting and impressive hypothesis formulated by Jäger (1954) and Seifert (1954) in which they suggested that the crystalline lattice surface of the quartz would act as a matrix on which cellular proteins would reform and consequently be denatured. The reforming of the proteins would cause them to assume the shape and properties of fibrous proteins, hence the capacity of free crystalline silica for producing fibrous tissue. This theory is supported by the fact that amorphous silica is far less fibrogenic than crystalline silica (Rüttner, Willy, and Baumann, 1954).

The arguments on the solubility hypothesis and on the physical hypothesis of the action of surfaces led to numerous additional investigations. In an excellent critical paper, King, Zaidi, and Nagelschmidt (1956) summarized and discussed all the points for and against the theory of solubility. The facts which contradict the validity of this theory as originally stated are the discrepancy between the solubility of various forms of free silica and their fibrogenic action, and the improbability that there is polymerized silicic acid in the tissues. King himself arrived at the conclusion that the solubility of the silica could not serve itself to explain the pathogenesis of silicosis.

Jäger has ably illustrated the points in favour of the theory of surface action. However, he did not succeed in explaining why certain non-crystalline forms of silica, such as condensation silica (Policard and Collet, 1954), have some fibrogenic action. Jäger also has not explained why areas of massive fibrosis are formed, nor why other mineral dusts alone or in combination with a small percentage of quartz can, in certain conditions, cause massive fibrosis.

It must be remembered that the hypotheses of chemical action and surface action were intended more to define the aetiological agent rather than the pathogenic mechanism of silicosis. They state that it is either dissolved silicic acid or silica crystals as such which cause fibrosis; but how these factors actually induce the formation of this particular hyaline fibrous tissue of silicosis has never been satisfactorily explained. The theory of Holt and Osborne (1953) that polymerized silicic acid acts like mucopolysaccharides, facilitating and directing the formation of fibrils and hence the production of collagen, and the one proposed by Jäger that connective tissue formation would be induced directly by a fibrous transformation of proteins 
absorbed on the crystalline lattice of quartz are not convincing. If it were, in fact, so, it still would be difficult to explain the varieties, extension, and evolution of silicotic fibrous tissue, and particularly the peculiar type of hyaline and its capacity for originating confluent masses, whose dimensions are out of proportion to the surface of quartz crystals which may be found in them.

The failure of mechanical, chemical, and physical theories to explain the pathogenesis of silicosis, and the belief that (Vorwald, 1950) inborn or acquired peculiarities of the subject may influence the beginning and development of this disease have prompted other approaches to the pathogenic problems. Policard, Croizier, and Martin (1937) and others have, for a long time, emphasized the importance of the tubercular factor, considering it indispensable in the genesis of silicotic nodules. Others (Cummins, 1940 and others) have affirmed that massive fibrosis is induced by the combined action of quartz and Koch bacilli, but they have not explained why and how this happens. In the last few years several investigators (Scheel, Smith, Van Riper, and Fleisher, 1954; Webster, 1956; Koch, 1949; Claeys, 1954) have suggested that the intervention of an immunological factor should be considered in relation to silicosis, and some of them have sought to demonstrate the antigenic properties of free silica; Antweiler and Hirsch (1956) with aerosil and Claeys with quartz reported negative results. But Scheel et al. (1954) succeeded in demonstrating that quartz coated with serum proteins and injected into the rabbit elicits the production of antibodies. Up to the present time it can be said that the belief that immunological factors play a rôle in the pathogenesis of silicosis has not been supported by any conclusive evidence.

We have been convinced from the first of the importance of the specific reaction of the host organism in the pathogenesis of silicosis, and have developed our research work in this direction. It has led us to believe that the immunological hypothesis is, at the moment, the only one which is able to explain the formation of hyaline nodules and fibrous tissue masses. Our guiding idea derives from the belief at the present time that an immunological pathogenesis is at the base of many so-called collagen diseases*, and in particular of rheumatoid arthritis, lupus erythematosus, periarteritis nodosa, and scleroderma. Silicosis can be considered, from many points of view, as a collagen disease.

*We use the term " collagen disease" because it is now widely used to define the group of diseases having in common that the connective tissue is involved to a smaller or greater extent. In fact, we are aware that this term is inappropriate since it is based on an element of the connective tissue, the collagen fibrils, which definitely do not partake in the pathological process.

\section{The Blood Protein Changes of Silicosis}

In 1950, Vigliani, Boselli, and Pecchiai recognized that in silicotic patients the blood proteins were almost always changed because of the increase in gamma globulins, and in cases with additional infections, also in alpha and beta globulins. This finding was confirmed by several investigators. All those who used a suitable technique have confirmed that in silicosis there is almost invariably an increase of serum gamma globulins and sometimes also of beta and alpha globulins. The blood protein changes in silicosis are associated with an increase in globulin-producing parenchymal cells in certain sites.

It is well known that antibodies belong mostly to the gamma globulin group; therefore, the increase in gamma globulins in silicosis might be either the expression of an increased antibody production or of an increase of gamma globulin production parallel to the production of antibodies (see Boyd and Bernard, 1937). In fact, changes in blood proteins similar to those found in silicosis are found in all the conditions of hyperimmunization and in all the collagen diseases. It is true, however, that serum gamma globulins are increased also in a wide variety of diseases not necessarily connected with an immunity reaction, and as yet it has not been established that the increased gamma globulins of silicotics are totally or in part antibodies.

\section{The Chemical Composition of Hyaline Tissue in Silicosis}

In our Institute, Pernis (1954, 1955), Pernis and Ghislandi (1956), and Pernis and Clerici (1957) have demonstrated that silicotic hyaline tissue differs in many respects from other physiological and pathological hyaline tissues such as that of scar tissue. True connective hyaline tissue is composed almost entirely of collagen fibres (Letterer, Gerok, and Schneider, 1955), but silicotic hyaline consists of $40 \%$ collagen, the remainder being globulin which must be considered as having an intermediate position between serum beta and gamma globulin. Silicotic hyaline tissue also contains carbohydrate in quantities of about $3 \%$ of the total amount of the proteins, and lipids corresponding to $20 \%$.

From a biochemical point of view (see Table 1), the silicotic hyaline tissue is very similar in its globulin, carbohydrate, and lipid content to amyloid substance. The so-called silicotic hyaline, then, consists of a reticular structure, within which serum globulins have precipitated. Indeed, very recently Pernis, Ceppellini, and Ghezzi (1957) demonstrated immunologically the presence of serum globulin in the hyaline tissue of silicosis. They isolated the hyaline tissue from pulmonary silicotic nodules freshly obtained at necropsy and homogenized the 
TABLE 1

CHEMICAL COMPOSITION OF HYALINE TISSUES OF SILICOSIS AND PERISPLENIC SYNECHIAE COMPARED WITH THAT OF LUNG AMYLOID FROM A CASE OF PRIMARY AMYLOIDOSIS

\begin{tabular}{|c|c|c|c|c|c|c|c|c|}
\hline \multirow{2}{*}{ Tissue } & \multicolumn{2}{|c|}{$\begin{array}{l}\text { Proteins } \\
\text { (\% total protein) }\end{array}$} & \multicolumn{4}{|c|}{$\begin{array}{c}\text { Carbohydrates } \\
\text { (g./100 g. protein) }\end{array}$} & \multicolumn{2}{|c|}{$\begin{array}{c}\text { Lipids } \\
\text { (g./100 g. protein) }\end{array}$} \\
\hline & Collagen & Globulins & $\begin{array}{l}\text { Hexuronic } \\
\text { Acids }\end{array}$ & Hexosamines & Hexoses & Methylpentoses & $\begin{array}{c}\text { Total } \\
\text { Lipids }\end{array}$ & Cholesterol \\
\hline $\begin{array}{l}\text { Hyaline tissue of } \\
\text { silicosis } \ldots \\
\text { Hyaline tissue of peri- } \\
\text { splenic synechiae } \ldots \\
\text { Lung amyloid }\end{array}$ & $\begin{array}{l}40 \cdot 2 \\
82 \\
41 \cdot 2\end{array}$ & $\begin{array}{l}59 \cdot 8 \\
18 \\
58 \cdot 8\end{array}$ & $\begin{array}{l}0 \\
\mathbf{0} \\
\mathbf{0}\end{array}$ & $\begin{array}{l}0 \cdot 58 \\
0 \cdot 26 \\
1 \cdot 12\end{array}$ & $\begin{array}{l}2 \cdot 13 \\
1 \cdot 04 \\
2 \cdot 20\end{array}$ & $\begin{array}{l}0 \cdot 28 \\
0 \cdot 31 \\
0 \cdot 36\end{array}$ & $\begin{array}{l}20 \cdot 1 \\
3 \\
14 \cdot 3\end{array}$ & $\begin{array}{l}3 \cdot 72 \\
0 \cdot 30 \\
3 \cdot 60\end{array}$ \\
\hline
\end{tabular}

tissue; the resulting suspension was then washed and re-homogenized six times in saline, in order to eliminate all traces of blood or lymph, and injected intraperitoneally into rabbits. The antisera which were obtained reacted with normal human serum electrophoretically separated in an agar plate after the technique of Grabar and Williams (1955), giving a single line of precipitation extending through the zones of beta and gamma globulins.

A similar result was obtained by reversing the procedure, that is, by absorbing a rabbit antiserum against whole normal human serum with homogenized and washed hyaline tissue of silicosis and afterwards using the absorbed antiserum in an immunoelectrophoresis experiment against whole normal human serum electrophoretically separated in an agar plate. Thus, after absorption with the hyaline tissue of silicosis but not with normal human lung, it could be seen that the long line of precipitation, which normally extends through the zones of beta and gamma globulin, had completely disappeared. The other lines of precipitation were unaffected by either absorption. It appears therefore that the hyaline tissue of silicosis contains a protein antigenically related to a serum protein whose electrophoretic mobility is that of beta or gamma globulin. In this connexion it is interesting to note that Williams and Grabar (1955) have shown that serum antibodies belong precisely to this fraction.

The immunological pathogenesis of amyloid has been accepted by many pathologists (Letterer, 1949; Koletsky and Stecher, 1939; Jaffé, 1926; Teilum, 1948; Jones and Frazier, 1950) who consider that the globulin content of this substance results from antigen-antibody precipitation localized in certain tissues. This concept has been recently supported also by immunohistochemical studies (Vazquez and Dixon, 1956). Thus, the presence in silicotic hyaline tissue of a large proportion of globulin, with characteristics intermediate between those of beta and gamma, makes it possible to consider this substance as similar to amyloid, that is, as an antigenantibody precipitate.

In addition, the existence of a large quantity of lipids in silicotic hyaline tissue agrees with this interpretation; for example, Horsfall and Goodner demonstrated as long ago as 1936 that antigenantibody precipitates may contain a proportion of co-precipitated lipids varying from $4 \%$ to $50 \%$ of the proteins.

The Action of the Tubercle Bacillus and its Products on the Development of Human and Experimental Silicosis

It has been known for decades that in the presence of a tubercular factor silicosis follows a more rapid and malignant course with a tendency for the nodules to condense and become confluent. Thus, these cases show a rapid increase in the production of fibro-hyaline tissue in the form of masses which sometimes become pseudotumoral and do not radically differ in microscopical structure from isolated silicotic nodules save for being more cellular. Neither do these masses show any substantial differences in chemical analysis, nor do they assume the histological characteristics of tubercular tissue, unless at a very late stage and then only in part.

So-called " infective silicosis" and "progressive massive fibrosis" have been considered as silicosis and anthracosilicotic pneumoconiosis which have been modified by the action of the Koch bacillus.

Until now, a satisfactory explanation has never been given for the mechanism by which the tubercular infection modifies silicosis and coal-miner's pneumoconiosis and produces a progressive confluent or massive fibrosis. This action can be explained by postulating an immunological pathogenesis of the formation of silicotic fibro-hyaline tissue. In 1942 Freund and McDermott showed that the immunological response to the introduction of a certain quantity of antigen can be greatly enhanced if the antigen is introduced into the host organism together with a certain amount of oily emulsion containing dead tubercle bacilli, the so-called " Freund's adjuvant". The technique of potentiating the antigen by associating it with dead tubercle bacilli has often been employed by immunologists and is found to be particularly useful in experimental auto-immunization. Assuming that quartz is capable, when introduced into the organism, of 
producing antigens by itself, or by modifying proteins or polysaccharides, these antigens would be greatly potentiated by the simultaneous action of tubercular antigens, and the production of antibodies would be consequently much greater, and a more extensive precipitation of the antigen-antibody complex in the form of hyaline would be expected.

The results of some animal experiments performed by Attygalle, Harrison, King, and Mohanty (1954) might in fact be due to the adjuvant action of dead tubercle bacilli. They observed that the fibrogenic activity of different dusts (anthracite, mine dust, kaolin) could be enhanced by the simultaneous administration of $5 \mathrm{mg}$. $/ \mathrm{kg}$ body weight of dead B.C.G. The fact that dead tubercle bacilli had the same enhancing effect on fibrosis in certain animals susceptible to tuberculosis (guinea-pigs) as well as in those highly resistant to it (rats), might be interpreted as a consequence of an unspecific boosting action of the dead tubercle bacilli rather than as a consequence of a tubercular infection. It is interesting that the doses of dead tubercle bacilli used by Attygalle and his colleagues were of the same order of magnitude as those contained in the doses of Freund adjuvant used in experimental immunology. Of course, we do not mean that tubercular infection by living tubercle bacilli could not enhance the fibrogenic action of different dusts, as this has been very convincingly shown by later experiments of Zaidi, Harrison, King, and Mitchison (1955), but we suggest that in either case at least a part of the action of tubercle bacilli in enhancing fibrosis might be due to an increased immune response after the liberation in the lung tissue of some components of the tubercle bacillus (amongst these, waxes have the highest adjuvant activity).

Late Appearance of Hyaline in Experimental Silicosis

In experimental silicosis the primary lesions are reticular nodules composed of macrophages, fibroblasts, and reticular fibrils. Typical silicotic hyaline never appears earlier than 40 days after the introduction of the dust even when the dust used is of the most fibrogenic type, such as quartz washed with hydrofluoric acid or tridymite. With the quartz generally used and probably still covered by the amorphous layer, the hyaline tissue appears after a period of six or more months, depending on the mode of introduction and the quantity used. One may therefore speak of the delay in the appearance of hyaline tissue in silicosis. The minimum period of delay ( 40 days) is equal to the time necessary to obtain a good production of antibodies in an animal injected with antigens of various types. The latent period in the appearance of silicotic hyaline is thus consistent with the hypothesis that the hyaline is the result of an antigen-antibody reaction.

\section{Capacity of Certain Dusts other than Quartz to Produce Massive Fibro-hyaline Tissue}

It has been maintained by many people that true pulmonary pneumoconiotic fibroses are only produced by dusts containing crystalline free silica or asbestos.

Recently Hale, Gough, King, and Nagelschmidt (1956) described six cases of massive fibrosis due to the inhalation of apparently quartz-free kaolin dust. The protein composition of the hyaline tissue from one of these cases of kaolinosis, in which death was due to massive pneumoconiosis, was determined in our Institute by Pernis, who showed that the hyaline material was very rich in globulins $(73 \%)$ and relatively poor in collagen $(27 \%)$; morphologically the picture was practically identical with that of massive silicosis. In our opinion, the cases of massive kaolinosis can be explained, assuming that under certain conditions, e.g., in chronic, torpid tubercular infection, certain dusts other than quartz may induce or increase an antibody reaction with antigen-antibody precipitation at sites of dust deposits. Kaolin has been known for some time as a good adjuvant to immune reactions.

The facts so far mentioned fit the hypothesis of the immunological genesis of fibro-hyaline tissue of silicosis and progressive massive fibrosis. If one accepts that the hyaline results from an antigenantibody precipitate where the antigen is produced by the action of dust alone, or of dust plus an infection, it is easy to explain the formation of silicotic nodules and fibrous masses. It also explains the slow progressive course of the disease even after cessation of exposure to the dust, the aggravating and potentiating effect of infection, particularly that of tuberculosis, the occasional capacity of dusts, generally considered to be capable of producing little or no fibrosis, to induce the formation of hyaline tissue, and the variations of the individual reaction to inhalation of dust.

On the other hand objections can be made to the immunological hypothesis of silicosis, principally the following.

Absence of Typical Allergic Reactions.-This objection is not valid if one supposes that in silicosis there is a slow and continuous production of antigens and a consequent continuous desensitization. Antibodies are produced without allergic symptoms (e.g., eosinophilia, or symptoms of anaphylactic shock, etc.) in animals continually injected with antigens for the production of antisera.

Production of Silicosis after Relatively Large Quantities of Quartz.-If silicosis were an allergic 
disease, the small quantities of quartz inhaled physiologically should be sufficient to produce it; however, it is essential to remember that in our concept silicosis is an immunological but not an allergic disease. The analogy of silicotic hyaline and of amyloid suggests that silica (and therefore antigen) must be introduced in considerable amount, concentration, and duration in order to produce the disease. Similarly, in experimental amyloidosis produced with casein- $\mathrm{Na}$, repeated and relatively large doses of this heterogeneous protein are necessary.

Lack of Serological Data Characteristic of Autoantibody Diseases.-Serological signs, considered typical of auto-antibody diseases, such as increased haemolysis, false positive Wassermann reactions, positive Coombs and cold agglutinin tests, are not normally observed in silicosis. It can be pointed out that these signs appear only in syndromes due to antibodies against blood cells and in those with a rather acute course. Silicosis is a disease localized in the lungs and neighbouring glands and follows a comparatively slow course. Also Saita and Arrigoni Martelli (1956) have recently shown the presence of cold agglutinin up to 1 in 60 in titre and an increase in the anticomplementary activity in the serum in a certain percentage of silicotic patients.

Capacity of Silica to Induce Auto-antigens and Antibodies.-Some experiments on the capacity of silica to induce the formation of auto-antigens and auto-antibodies have given negative results. Friedberg and Lendle (1956) as well as Antweiler and Hirsch (1956) did not succeed in inducing the formation of auto-antigens and auto-antibodies in guinea-pigs and rabbits injected with colloidal silicic acid, for colloidal silica does not produce true silicosis. On the other hand, Scheel and his colleagues did succeed in obtaining the formation of anti-protein auto-antibodies with crystalline silica.

\section{Suggested Hypotheses}

If silicosis is to be considered as a disease with an immunological pathogenesis, it may be interesting to speculate as to how free silica might provoke or increase the formation of antigens and consequently of antibodies. Silica might act in the following ways: (1) Silica itself might act as an antigen. (2) Silica might induce the formation of auto-antigens. (3) Silica might act as a booster of hetero-antigens. (4) Silica might induce the liberation of autoantigens indirectly by killing a comparatively large number of cells. These hypotheses must be discussed in the light of our limited present knowledge.

Silica Itself an Antigen.-A crystal of free silica might have antigenic properties because of its particulate nature and its specific crystalline structure. However, the attempts of Claeys to demonstrate anti-silica antibodies in the serum of silicotic patients were not conclusive. The fact that hyaline tissue is found even at a considerable distance from the quartz crystals might be explained by assuming that colloidal silicic acid is the antigen; however, the presence of highly polymerized colloidal silica in pulmonary interstitial tissue is considered uncertain, and, by some investigators (Paterson and Wheatley, 1955), even improbable. Researches by Antweiler on the antigenic properties of aerosil have given negative results.

Silica Inducing Auto-antigens. - Silica could induce the production of auto-antigens from proteins or polysaccharides. It is well known that quartz adsorbs proteins and that the adsorbed proteins can easily be denatured, and there could theoretically be three adsorption patterns of proteins on particulate matter: (1) Simple adsorption, (2) adsorption with denaturation, (3) adsorption with denaturation and specific rearrangement of protein molecules after a particular model of crystalline lattice.

It is clear that the production of auto-antigens would be facilitated most by the formation of proteins denatured according to the third pattern, which is actually what would occur according to Jäger and Seifert's hypothesis. That theory is based on the possibility of the quartz surface producing a specific altered protein on the crystal surface. With or without this specific rearrangement postulated by Jäger, the proteins adsorbed by quartz surfaces might be denatured and thus act as auto-antigens. Scheel and his colleagues (1954) have investigated whether quartz denatures proteins in such a way as to form auto-antigens and appear to have been able to demonstrate that this in fact does happen after intravenous injections in the rabbit of quartz covered with homologous serum proteins; this does not occur with other dusts.

Holzapfel (1952) recognized that certain carbohydrates, and in particular galactose, have a marked tendency to be adsorbed on quartz. The absorption of certain tissue polysaccharides on silica crystals could give them auto-antigenic properties.

Silica as a Booster of Hetero-antigens. - If one considers quartz as an antigen on its own account, or as being capable of producing auto-antigens, the Koch bacillus would act in human as well as experimental pneumoconioses as a Freund adjuvant. The " Freund adjuvant" is actually formed of dead tubercle bacilli emulsified in "aquaphor" and paraffin oil and it is used to potentiate a numerous series of antigens and auto-antigens in experimental immunology. 
Also it is known that some finely powdered dusts may increase the immunological response to different antigens. Those most often used for this purpose are $\mathrm{AlPO}_{4}, \mathrm{Al}_{2}\left(\mathrm{SO}_{4}\right)_{3}$, kaolin and other mineral dust having marked adsorbent properties. This action is probably due to their capacity for adsorbing antigens, which are therefore kept in a high local concentration and then diffuse slowly; more antibodies are thus produced, compared with antigens which diffuse rapidly (and are thereby diluted) in blood and body fluids. It is possible that the ability of these mineral dusts to cause macrophagic granulomata at the site of inoculation plays a rôle in determining an increase of the antibody response. Aluminium phosphate has been shown by King, Harrison, Mohanty, and Nagelschmidt (1955) to produce a mild fibrosis in the rat lung.

Quartz, whose crystalline lattice is identical with that of $\mathrm{AlPO}_{4}$, might conceivably have the property of increasing the antibody response to different exogenous antigens which reach the zone of the silicotic granuloma. This might even occur with tubercular antigens; thus it would not be the tubercle bacillus but quartz itself acting as a booster. It is possible, however, in this case that both quartz and the tubercle bacillus act as boosters and as sources of antigens at the same time, thus potentiating each other and producing a large increase in antibody response.

The possibility that some mineral dusts might, after their penetration in the lung, act as boosters of antigens of bacterial origin might explain some cases of massive fibrosis after inhalation of large amounts of kaolin; King et al. (1955) were able in animal experiment to produce a pulmonary fibrosis by means of kaolin and killed tubercle bacilli, and are of the opinion that the synergistic action of kaolin and tubercle bacilli might be the cause of the cases of massive fibrosis observed in kaolin workers by Hale et al. (1956).

Indirect Liberation of Auto-antigens by Silica.This has been suggested to us by Dr. Klosterkötter; it is in accord with the observation that the amount of fibrohyaline tissue generally shows a rough parallelism with the number of cells which have been damaged by quartz. Jötten and Klosterkötter (1952) have stated that in the genesis of silicosis the quartz acts as a "deposit poison" which slowly sets free the substances which determine a fibrogenic reaction. A similar opinion was put forward by King in saying that silica, in order to produce silicosis, must dissolve slowly enough to determine a prolonged reaction. These ideas agree with our opinion that the formation of fibrohyaline tissue which follows the action of quartz is dependent upon a slow but continued production of antigens.
It is now useful to consider hypothetically where the antibodies to these antigens might be produced. Some hints may be obtained from experimental immunology. A common method for obtaining an increased antibody response is that of introducing an antigen previously precipitated with $\mathrm{AlPO}_{4}$, so that a granuloma forms, and it will be for a comparatively long time a source of concentrated antigen and a site of antibody production (White, Coons, and Connolly, 1955); it is interesting to note that the antigen-antibody precipitate which gradually takes place inside the granuloma has a strong tendency to be adsorbed by the collagen fibres which have been actively formed in the meantime.

Perhaps events might be similar in the silicotic granuloma which could therefore be at the same time a source of antigens and antibodies; the antigenantibody precipitation would then begin in the central part of the nodule and the precipitate be absorbed by the reticular fibres with the formation of hyaline tissue as a result. In the meantime the proliferation of the peripheral cells could continue, thus increasing the size of the nodule. But it is possible that the antibody production is not limited to the cells of the silicotic granuloma. In the experiments of Coons et al. antibody production was not limited to the cells of the $\mathrm{AlPO}_{4}$ granuloma but antibodies were produced to an even greater extent by cells in the regional lymph nodes. In silicosis the hilar lymph nodes might similarly be considered as a source of antibodies until they are totally invaded by the silicotic fibrosis, and in acute silicosis the hilar lymph nodes are swollen and very rich in cells $(\mathrm{Di}$ Biasi, 1949). Moreover, if the auto-antigens produced by the action of quartz were soluble, antibodies might be formed in other sites. Vigliani et al. (1950) have observed in silicosis an active proliferation of histiocytes and plasma cells in many extrapulmonary tissues, and a proliferation of reticular and plasma cells in the bone marrow of silicotics has been reported by Saita and Di Naro (1951) and by Lachnit (1954).

\section{Conclusion}

We consider that the immunological hypothesis of the pathogenesis of the hyaline tissue of silicosis and of progressive massive fibrosis is a working hypothesis which opens a new and promising field of research. It brings forward possible analogies between silicosis and some collagen diseases characterized by the presence of fibrinoid and amyloid substances, whose immunological origin appears increasingly probable.

The hypothesis is interesting in the emphasis it places on the rôle of the host organisms rather than on the action of silica. It is consistent, too, with a 
number of the physical and chemical properties of silica but does not rely on them solely to explain the genesis of silicosis. Attention is focused more on the reaction of tissues and of the whole organism than on the toxic or irritating action of the foreign body. The hypothesis that this reaction is not confined to the mere cellular damage produced by silica but is concerned with the production of auto-antigens and auto-antibodies is in accord with some peculiarities which are common to silicosis and other diseases whose immunological genesis is very probable, that is, the formation of a hyaline substance chemically similar to amyloid, and the progressive course of the disease. Indeed, even when no more dust is inhaled, the formation of hyaline tissue goes on and leads to a massive fibrosis whose extension is much greater than that which might conceivably be produced by a purely toxic or surface action of the dust.

The immunological hypothesis outlined needs more precise verification, chiefly in regard to the possible mechanism of the formation of autoantigens capable of inducing active production of auto-antibodies.

\section{Summary}

The histogenesis of silicotic nodules can be divided into two stages: first, cellular proliferation and the formation of reticular fibrils, and second, hyaline precipitation upon the fibrils. This second stage makes silicosis a disabling and progressive disease as compared with the uncomplicated pneumoconioses caused by inert dusts.

Our work on the origin of the hyaline stage of silicosis leads to the hypothesis that the hyaline tissue has an immunological origin and corresponds to an antigen-antibody precipitation. This opinion is supported by the following points:-

(1) The chemical composition of hyaline tissue of silicosis corresponds to that of amyloid, a substance for which an immunological origin is commonly accepted.

(2) Globulins have been demonstrated immunologically in silicotic nodules which were of the beta and gamma variety.

(3) Some aspects of silicosis, such as the increased gamma-globulin content of the blood, the proliferation of histiocytes and plasma cells in the reticuloendothelial system, the progressive course of the disease, and the variation in the reactions of individuals to inhaled silica dust, lead us to apply to silicosis the concept of " collagen disease". Many of the collagen diseases have a recognized immunological origin.

(4) The influence of tuberculosis in producing massive hyaline fibrosis in silicotic patients can be explained on an immunological basis, assuming that the tubercle bacilli potentiate an antibody reaction, such as when Freund's adjuvant is used.

The possible mechanisms by which quartz could induce the formation of antigens capable of starting an antibody reaction are discussed.

This research has been carried out with the financial support of the High Authority of the European Community for Coal and Steel.

\section{REFERENCES}

Antweiler, H., and Hirsch, E. (1956). Arch. Gewerbepath. Gewerbehyg., 14, 678.

Attygalle, D., Harrison, C. V., King, E. J., and Mohanty, G. P. (1954), Hrit. J. industr. Med., 11, 245 .

Boyd, W. C., and Bernard, H. (1937). J. Immunol., 33, 111.

Claeys, C. (1954). Rev. méd. minière, 7,22

Cummins, S. L. (1940). Brit. J. exp. Path., 21, 64.

Dantin-Gallego, J. (1948). Nuevas Ideas etio-patogenicas sobre la Silicosis. Publicaciones de la Jefatura provincial de Sanidad, Madrid.

Di Biasi, W. (1949). Beitr. Silikose-Forsch., No. 3.

Evans, S. M. (1948). J. industr. Hyg., 30, 353 .

Freund, J., and McDermott, K. (1942). Proc. Soc. exp. Biol. (N.Y.), $49,548$.

Friedberg, K. F., and Lendle, L. (1956). Beitr. Silikose-Forsch., No. 41, p. 1 .

Grabar, P., and Williams, C. A., Jr. (1955). Biophys. Biochim. Acta, $17,67$.

Gye, W. E., and Purdy, W. J. (1922). Brit. J. exp. Path., 3, 86.

Hale, L. W., Gough, J., King, E. J., and Nagelschmidt, G. (1956). Brit. J. industr. Med., 13, 251 .

Holt, P. F., and Osborne, S. G. (1953). Ibid., 10, 152.

Holzapfel, L. (1952). Beitr. Silicose-Forsch., No. 15.

Horsfall, F. L., and Goodner, K. (1936). J. exp. Med., 64, 583.

Jaffé, R. H. (1926). Arch. Path. (Chicago), 1, 25.

Jäger, R. (1954). In Die Staublungenerkrankungen, Vol. 2, p. 142, ed. Jötten, K. W., Klosterkötter, W., and Pfefferkorn, G., Steinkopff, Darmstadt.

Jones, R. S., and Frazier, D. B. (1950). Arch. Path. (Chicago), 50, 366.

Jötten, K. W6., and Klosterkötter, W. (1952). Arch. Hyg. (Berl.),

Kikuth, W6. 1. (1956). Dtsch. med. Wschr., 81, 1633.

King, E. J. (1947). Occup. Med., 4, 26.

, Harrison, C. V., Mohanty, G. P., and Nagelschmidt, G. (1955). J. Path. Bact., 69, 81.

Zaidi, S. H., and Nagelschmidt, G. (1956). A.M.A. Arch. industr. Hlth, 13, 133 .

Koch, W. (1949). Frankfurt Z. Path., 60, 58.

Koletsky, S., and Stecher, R. M. (1939). Arch. Path. (Chicago), 27, 267.

Lachnit, . (1954). Wien. Z. inn. Med., 35, 49.

Letterer, E. (1949). J. Path. Bact., 61, 496.

Gerok, W., and Schneider, G. (1955). Virchows Arch path Anat., 327, 327.

Parmeggiani, L. (1950). Med. d. Lavoro, 41, 124.

Paterson, M. S., and Wheatley, K. H. (1955). Safety in Mines Research Establishment. Research Report No. 124.

Pernis, B. (1954). In Die Staublungenerkrankungen, Vol. 2, p. 293. Steinkopff, Darmstadt.

(1955). Med. d. Lavoro, 46, 668

and Clerici, E. (1957). Ibid., 48, 449.

and Ghislandi, E. (1956). Ibid., 47, 460

, Ceppellini, R., and Ghezzi, I. (1957). Ibid., 48, 380

Policard, A., and Collet, A. (1954). A.M.A. Arch. industr. Hyg., 9, 389

-, Croizier, L., and Martin, E. (1937). Ann. Anat. path., 14, 587. Path. Bakt., 17, 35 .,

Saita, G., and Arrigoni Martelli, E. (1956). Med. d. Lavoro, 47, 367. Saita, G., and Di Naro, C. (1951). Ibid., 42, 201.

Scheel, L. D., Smith, B., Van Riper, J., and Fleisher, E. (1954). A.M.A. Arch. industr. Hyg., 9, 29.

Seifert, H. (1954). In Die Staublungenkrankungen, Vol. 2, p. 199.

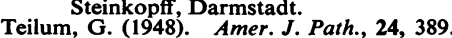

Vazquez, J. J., and Dixon, F. J. (1956). J. exp. Med., 104, 727.

Vazquez, J. J., and Dixon, F. J. (1956). J. exp.

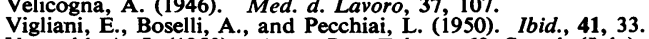

Vorwald, A. J. (1950).' Amer. Rev. Tuberc., 62, Suppl. (July), p. 13 Vorwald, A. J. (1950). Amer. R R.
Webster, I. (1956). Leech, 26, 38.

White, R. G., Coons, A. H., and Connolly, J. M. (1955). J. exp. Med., 102, 73 .

Williams, C. A., Jr., and Grabar, P. (1955). J. Immunol., 74, 397.

Zaidi, S. H., Harrison, C. V., King, E. J., and Mitchison, D. A. (1955), Brit. J. exp. Path., 36, 539, 545, 553 . 